\title{
GIANT SPLENIC ARTERY PSEUDO ANEURYSM MASQUERADING AS BLEEDING PER RECTUM - A RARE CASE
}

Bhupesh Tirpude ${ }^{1}$, Hemant Bhanarkar2, Sanjay Dakhore ${ }^{3}$, Dhiraj Surgul ${ }^{4}$

\section{HOW TO CITE THIS ARTICLE:}

Bhupesh Tirpude, Hemant Bhanarkar, Sanjay Dakhore, Dhiraj Surgule. "Giant splenic artery pseudo aneurysm masquerading as bleeding per rectum - a rare case". Jo urnal of Evolution of Medical and Dental Sciences 2013; Vol. 2, Issue 44, November 04; Page: 8569-8573.

ABSTRACT: Splenic artery aneurysm are rare entity, we report a case of 40 year old male presenting with hypovolemic shock and massive bleeding per rectum secondary to spleenic artery aneurysm rupture into the colon. Patient underwent exploratory laparotomy and definitive procedure was done.

KEY WORDS: Splenic artery aneurysm 1: shock 2 : bleeding per rectum 3: chronic pancreatitis;

INTRODUCTION: A patient of bleeding per rectum with hypovolemic shock in previously known case of pancreatitis must be thoroughly evaluate. There may be possibility of splenic artery aneurysm which might communicate with colon.

CASE REPORT: A 40 year old male patient came to casualty with complaint of severe bleeding per rectum, weakness, sweating, mild pain in abdomen. On general examination patient had severe pallor, blood pressure -80 systolic, respiration 28 , pulse rate 120 / minute, mild oedema feet and abdomen was soft non tender, no palpable lump. On per rectal examination fresh bleeding with clot was present. Before coming to casualty he had undergone colonoscopy for his complaint but the procedure was abandoned due to heavy bleeding.

Patient had past h/o single episode of bleeding per rectum one year back, which was treated conservatively. Patient is also known case of chronic pancreatitis.

On investigation significant laboratory studies included haemoglobin $4.2 \mathrm{gm} / \mathrm{dL}$, with mildly raised liver enzyme. Patient was immediately shifted to radiology department for ultra sound abdomen which suggest large mass at splenic hilum reaching upto descending colon. On C. T. scan abdomen, there was large splenic artery aneurysm approximately $10 \mathrm{~cm} \times 8 \mathrm{~cm}$ communicating with splenic flexure of colon, with rent size $2.00 \mathrm{~cm}$ and changes of chronic pancreatitis[Fig-1]. Since patient was unaffordable for radiological intervention, he was immediately shifted to emergency operation theatre for exploration. On exploration there was large aneurysm extending from splenic hilum communicating with splenic colon[Fig-2]. A splenic artery was dissected proximal to aneurysm and ligated. This was followed by excision of aneurysm along with involved part of colon with end to end anastomosis and splenectomy. Patient had local wound site infection and hypoprotenemia, but he walked out of hospital on day $16^{\text {th. }}$ 


\section{CASE REPORT}

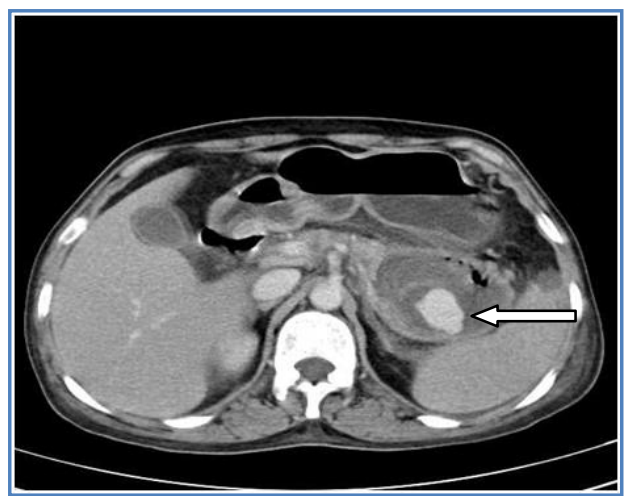

Figure 1: shows splenic artery

aneurysm rupture in to the colon.

Figure 1: Shows large splenic aneurysm communicating with colon.

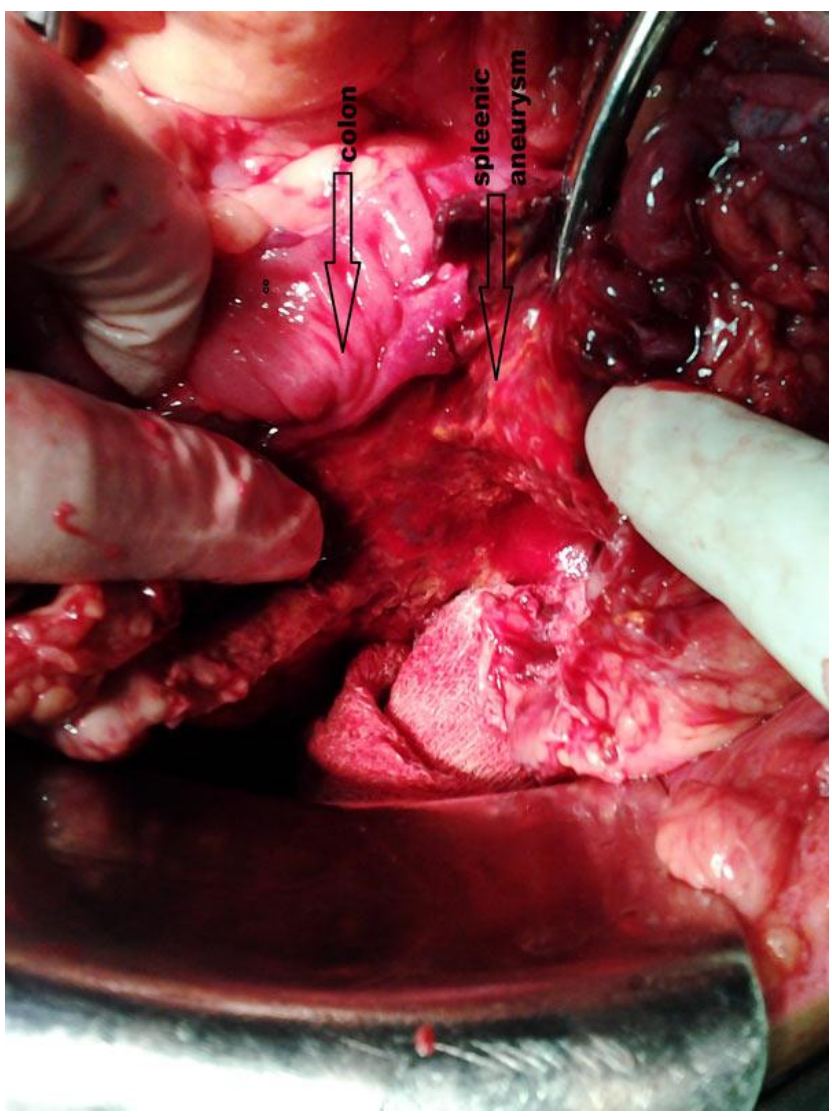

Figure 2 : shows large spleenic aneurysm communicating with colon.

DISCUSSION: Splenic artery aneurysm is the most common form of the splanchnic artery aneurysm [2]. Most of the aneurysms are caused by degenerative atherosclerosis, portal hypertension secondary to liver cirrhosis, pancreatitis, pregnancy, congenital causes such as anomalous origin, Berry aneurysm, arteriovenous malformation $[2,9,7,11,5,10]$.

Patients with a ruptured aneurysm can present with acute abdomen, hypotension, and hemorrhagic shock [2].There have been reports of haemorrhage into stomach, colon and pancreas $[13,14,15]$. Splenic artery pseudo aneurysm rupturing into colon presenting as bleeding per rectum is very rare [14]. Splenic artery aneurysms are usually diagnosed incidentally. Diagnosis is usually made by contrast enhanced computed tomography scans and the lesions are imaged during the 


\section{CASE REPORT}

arterial phase [2]. Doppler and magnetic resonance imaging are important adjunct in diagnosis. Digital subtraction angiography or transcatheter angiography via femoral artery is considered gold standard investigation because of its therapeutic potential [2].

True splenic artery aneurysms are rare but potentially life threatening entities. There is an estimated prevalence of $0.02-0.1 \%$ in general autopsies but their true incidence is difficult to determine as these are mostly asymptomatic [4].

Pseudo aneurysms of the splenic artery are rare and fewer than 200 cases are reported in English literature till now. Giant pseudo aneurysms (more than $5 \mathrm{~cm}$ in size) of splenic artery are also extremely rare and about 20 cases have been reported, largest being $19 \mathrm{~cm}$ as reported by Goldberg et al. in 2010. [19,20] The most common cause is considered to be chronic pancreatitis. Pancreatic enzymes are thought to cause necrotizing arteritis with destruction of vessel architecture and fragmentation of elastic tissue leading to pseudo aneurysm formation.[11] Risk of rupture is higher in pseudo aneurysms as compared to true aneurysms and can be as high as $37 \%$ with mortality approaching $90 \%$ when untreated. Besides rupture, aneurysms can also be complicated by splenic infarction or compression of adjacent biliary tree causing pseudo-obstructive jaundice. Thus once the diagnosis is made immediate definite intervention is mandatory $[19,20]$.

In our case patient had chronic pancreatitis with similar complaint in past which was managed conservatively. Also rent was big and needed more material for coiling. Patient was unaffordable hence surgery was done.

Splenic artery aneurysms can be treated by endovascular or surgical procedure [17]. Open surgical procedure depends on location of the lesion. Aneurysms of proximal splenic artery can be managed by ligation of splenic artery at both the ends of lesion and excision of aneurysm with splenic preservation. $[6,8,16]$ Endovascular techniques are also a good alternative to surgical approach with $80-92 \%$ success rate. Coil embolization, detachable balloon occlusion or stent graft may be used. Splenic abscess formation, splenic infarct, high rate of recurrence and inability to perform in larger lesions are drawbacks of endovascular techniques [17]. However, even with availability of less invasive procedures such as laparoscopy or endovascular treatment, open surgery is mostly preferred because of lower recurrence and complication rate. [16]

CONCLUSION: Whenever there is a case of severe bleeding per rectum with hypovolemic shock in known a case of chronic pancreatitis one should keep possibility of splenic artery aneurysm communicating with colon.

\section{REFERENCES:}

1. R. Guillon, J. M. Garcier, and J. M. Garcier, "Management of splenic artery aneurysms and false aneurysms with endovascular treatment in 12 patients," Cardio Vascular and Interventional Radiology, vol. 26, no. 3, pp. 256-260, 2003. View at Publishe,r View at Google Scholar View at Scopus.

2. S. F. Pasha, P. Gloviczki, A. W. Stanson, and P. S. Kamath, "Splanchnic artery aneurysms," Mayo Clinic Proceedings, vol. 82, no. 4, pp. 472-479, 2007. View at Publisher View at Google Scholar View at Scopus.

3. C.-F. Liu, C.-T. Kung, B.-M. Liu, S.-H. Ng, C.-C. Huang, and S.-F. Ko, "Splenic artery aneurysms encountered in the ED: 10 years' experience," American Journal of Emergency Medicine, vol. 


\section{CASE REPORT}

25, no. 4, pp. 430-436, 2007. View at Publisher, View at Google Scholar, View at PubMed, View at Scopus

4. Trastek VF, Pairolero PC, Joyce JW, Hollier LH, Bernatz PE. Splenic artery aneurysms. Surgery. 1982;91:694-699. [PubMed]

5. Sunagozaka H, Tsuji H, Mizukoshi E, Arai K, Kagaya T, Yamashita T, Sakai A, Nakamoto Y, Honda M, Kaneko S. The development and clinical features of splenic aneurysm associated with liver cirrhosis. Liver Int. 2006; 26:291-297. doi: 10.1111/j.1478-3231.2005.01231.x. [PubMed] [Cross Ref]

6. Abad C, Montesdeoca-Cabrera D, Saez-Guzman T. Splenic artery aneurysm. Review of two surgically operated cases. Ann Med Interna. 2006; 23:130-132. [PubMed]

7. Selo-Ojeme DO, Welch CC. Review: spontaneous rupture of splenic artery aneurysm in pregnancy. Eur J Obstet Gynecol Reprod Biol. 2003;109:124-127. doi: 10.1016/S03012115(03)00094-0.[PubMed] [Cross Ref]

8. Migliara B, Lipari G, Mansueto GC, Riva F, Baggio E. Managing anomalous splenic artery aneurysm: a review of the literature and report of two cases. Ann Vasc Surg. 2005;19:546-552. doi: 10.1007/s10016-005-5048-0.[PubMed] [Cross Ref]

9. Imai MA, Kawahara E, Katsuda S, Yamashita T. Berry splenic artery aneurysm rupture in association with segmental arterial mediolysis and portal hypertension. Pathol Int. 2005;55:290-295. doi: 10.1111/j.1440-1827.2005.01827.x.[PubMed] [Cross Ref]

10. Agrawal A, Whitehouse R, Johnson RW, Augustine T. Giant splenic artery aneurysm associated with arteriovenous malformation. J Vasc Surg. 2006;44:1345-1349. doi: 10.1016/j.jvs.2006.06.049.[PubMed] [Cross Ref]

11. Iki T, Tsunoda T. Giant splenic artery aneurysm associated with chronic pancreatitis. Dig Surg. 2003;20:10-11. doi: 10.1159/000068853.[PubMed] [Cross Ref]

12. Park H. Rupture of splenic artery aneurysm. Am J Forensic Med Pathol. 1992;13:230-232. doi: 10.1097/0000 0433-199209000-00013. [PubMed] [Cross Ref]

13. Inglis FG, McKee NH. Unusual cause of upper gastrointestinal bleeding: rupture of splenic artery aneurysm into stomach with survival. Can J Surg. 1972;15:276-278.[PubMed]

14. Bishop NL. Splenic artery aneurysm into the colon diagnosed by angiography. Br J Radiol. 1984;57:1149-1150. doi: 10.1259/0007-1285-57-684-1149.[PubMed] [Cross Ref]

15. Soeno T, Kakizaki G, Fujiwara Y, Noto N, Saito T. Massive haemorrhage into the upper digestive tract due to rupture of splenic artery aneurysm into the pancreas. Am J Gastroenterol. 1974;61:55-62.[PubMed]

16. Ha JF, Sieunarine K. Laparo scopic splenic artery aneurysm resection: review of current trends in management. Surg Laparosc Endosc Percutan Tech. 2009;19:e67-e70. doi: 10.1097/SLE.0b013e31819bd4e7.[PubMed] [Cross Ref]

17. Roland J, Brody F, Venbrux A. Endovascular management of a splenic artery an eurysm. Surg Laparosc Endosc Percutan Tech. 2007;17:459-461. doi: 10.1097/SLE.0b013e31814a5772.[PubMed] [Cross Ref]

18. Stanley JC, Thompson NW, Fry WJ. Splanchnic artery aneurysms. Arch Surg. 1970;101:689697.[PubMed]

19. Vishal gupta et al. Giant pseudo aneurysm of splenic artery: J. Pancreas (online 2011) Mar 09; 12(2):190-193. 


\section{CASE REPORT}

20. Goldberg RF, Maley W, Kennedy EP, Yeo CJ, Lavu H. Giant splenic artery pseudoaneurysm. J Gastrointestinal surgery 2010 Nov 25.

\section{AUTHORS:}

1. Bhupesh Tirpude

2. Hemant B hanarkar

3. Sanjay Dakhore

4. Dhiraj Surgule

\section{PARTICULARS OF CONTRIBUTORS:}

1. Assistant Professor, Department of Surgery, Indira Gandhi Govt. Medical College, Nagpur.

2. Assistant Professor, Department of Surgery, Indira Gandhi Govt. Medical College, Nagpur.

3. Assistant Professor, Department of Surgery, Indira Gandhi Govt. Medical College, Nagpur.
4. Assistant Professor, Department of Surgery, Indira Gandhi Govt. Medical College, Nagpur.

\section{NAME ADDRESS EMAIL ID OF THE CORRESPONDING AUTHOR:}

Dr. Bhupesh H. Tirpude,

302, c-wing, Majes tic Height, Shivaji Nagar, Hill Road,

Nagpur - 440010.

Email - btirpude@gmail.com

Date of Submission: 20/10/2013.

Date of Peer Review: 21/10/2013.

Date of Acceptance: 25/10/2013.

Date of Publishing: 30/10/2013 